\title{
Anti-Inflammatory and Analgesic Effects of Aqueous Extract of Stem Bark of Ceiba pentandra Gaertn
}

\author{
Romaric De Garde Elion Itou ${ }^{1}$, Rokia Sanogo ${ }^{2}$, Arnaud Wilfrid Etou Ossibi ${ }^{1}$, \\ Freddy Gelase Nsondé Ntandou ${ }^{1}$, Radard Ondelé1, Bonaventure Max Pénemé1, \\ Nadége Okiémy Andissa1, Drissa Diallo², Jean Maurille Ouamba ${ }^{3}$, Ange Antoine Abena ${ }^{1}$ \\ ${ }^{1}$ Laboratoire de Biochimie et Pharmacologie, Faculté des Sciences de la Santé, Université Marien Ngouabi, \\ Brazzaville, Congo \\ 2Département Médecine Traditionnelle (DMT), Faculté de Médecine, de Pharmacie et d'Odonto-Stomatologie, \\ Université de Bamako, Bamako, Mali \\ ${ }^{3}$ Unité de Chimie du Végétale et de la vie, Faculté des Sciences et Techniques, Université Marien Ngouabi, \\ Brazzaville, Congo \\ Email: romaricdegarde@yahoo.fr
}

Received 27 September 2014; revised 26 October 2014; accepted 15 November 2014

Copyright (C) 2014 by authors and Scientific Research Publishing Inc.

This work is licensed under the Creative Commons Attribution International License (CC BY).

http://creativecommons.org/licenses/by/4.0/

(c) (i) Open Access

\begin{abstract}
Anti-inflammatory and analgesic effects of the aqueous extract of the stem bark of Ceiba pentandra Gaertn (Bombacaceae) were recorded in rat and mice. Inflammation was induced by carrageenan and cotton pellet. The pain was studied using analgesymeter, Koster and hot plate Methods. Aqueous extract (400 and $800 \mathrm{mg} / \mathrm{kg}$ ) of Ceiba pentandra presents a significant anti-inflammatory and analgesic activity. Flavonoïds present in the extract seem to be responsible for the activity.
\end{abstract}

\section{Keywords}

Analgesic, Anti-Inflammatory, Ceiba pentandra

\section{Introduction}

Ceiba pentandra (Bombacaceae) is a large tree reaching a height of $50 \mathrm{~m}$ and $2 \mathrm{~m}$ of diameter [1]. The plant is widely used in traditional medicine in the world [2]. In the African pharmacopeia, the plant is known for its antiseptic, anti-inflammatory, antispasmodic and diuretic properties [3]. In Republic of Congo, Ceiba pentandra Gaertn (Bombacaceae) is used in traditional medicine to treat stomach aches, asthma, rickets and diarrhoea [4]-[8] 
however no scientific data on its anti-inflammatory and analgesic effects is available in Congo-Brazzaville. That's why in this study, we aimed investigated anti-inflammatory and analgesic activities of Ceiba pentandra stem bark collected in Brazzaville, capital of the Republic of Congo.

\section{Materials and Methods}

\subsection{Materials}

\subsubsection{Vegetal Materiel}

The stem bark of Ceiba pentandra was collected in Brazzaville (Lycée Pierre Savorgnan de Brazza) in June 2008. Botanical identification of the plant material was done by Dr. A. Mousamboté, botanist systematist at the Institute of Rural Development. A voucher specimen was deposed at the Herbarium of Center of Studies on the Vegetable Resources (C.E.R.VE.) of Brazzaville and registered under the number 2529 of 20/06/1968.

\subsubsection{Animals}

Albinos rats weighing between 200 - $250 \mathrm{~g}$ of Faculty of Health Sciences of Marien Ngouabi University, and male and female albinos mice weighing 20 - 35 g provided by the National Center for Support and Fight against Diseases (CNAM) of Bamako in Mali were used. Animals were acclimated during one week before the experiments. They were fed and maintained under standard lighting conditions (12 hours light and 12 hours dark) at a temperature of $24^{\circ} \mathrm{C} \pm 1^{\circ} \mathrm{C}$. They were fasted for 24 hours before experiments, while water was given ad libitum.

\subsection{Methods}

\subsubsection{Aqueous Preparation}

$600 \mathrm{~g}$ of pulverized powder of Ceiba pentandra were mixed with 6 liters (L) of distilled water, and the mixture was boiled for $15 \mathrm{~min}$. After cooling and filtration, the filtrate was concentrated under vacuum in a rotary evaporator Büchi R-2I0 at a temperature of $55^{\circ} \mathrm{C} \pm 1^{\circ} \mathrm{C}$. The thick solution was then freeze-dryed using a system Heto Drywinner Edwards Pump. The dried extract obtained was kept for experiments.

\subsubsection{Anti-Inflammatory Activities}

Anti-inflammatory effect of aqueous extract of Ceiba pentandra was evaluated using two standard methods: the carrageenan induced paw oedema [9] and cotton pellet induced granuloma (chronic inflammation) models [10]. For each method, four groups of 5 rats were used. Animals were treated as follow: group control was treated with distilled water at the dose of $0.5 \mathrm{ml} / 100 \mathrm{~g}$; group 2 was treated with Diclofenac (Voltaren ${ }^{*}$ ), used as the reference drug, at a dose of $5 \mathrm{mg} / \mathrm{kg}$; group 3 and group 4 were treated with aqueous extract of Ceiba pentandra at the dose of 400 and $800 \mathrm{mg} / \mathrm{kg}$.

\subsubsection{Acute Inflammation Induced by Carrageenan}

Acute inflammation was induced by carrageenan [9]. One (1) hour after oral administration of products (distilled water, Diclofenac and aqueous extract), animals received $0.05 \mathrm{ml}$ of $1 \%$ carrageenan by sub-plantar administration at the right hind paw. The volumes $V o$ and $V t$ of paw oedema were measured using an Ugo Basile 7140 pletysmometer, Italy. The anti-inflammatory effect was evaluated by determining the percentage of inflammation inhibition (PI\%), using the following formula:

$$
\begin{aligned}
& V=V t-V o \\
& \% P I=\frac{(V t-V o) t-(V t-V o) t r}{(V t-V o) t} \times 100
\end{aligned}
$$

With: $V=$ volume of œdema; $V t=$ volume of the paw oedema at a time $t$; $V o=$ volume of the paw before induction of inflammation; $(V t-V o) t=$ volume of œdema of the control group of rats; $(V o-V t) t r=$ volume of œdema in the group of treated rats.

\subsubsection{Chronic Inflammation Induced by Cotton Pellets}

The effect of aqueous extract of dried and powdered bark of Ceiba pentandra was evaluated on the cotton pellet induced granuloma model [10]. $100 \mathrm{mg}$ of cotton pellets were sterilized at $60^{\circ} \mathrm{C}$ during $24 \mathrm{~h}$ and placed in the right 
interscapular region of animal after ether anesthesia and incision. The incision was closed by suture. Animals were then treated with drugs for seven (7) days. On the eighth day the granulation tissue with cotton pellet was removed, cleared of adhering tissue and placed at $60^{\circ} \mathrm{C}$ for $24 \mathrm{~h}$ and weighed. The anti-inflammatory effect was given by the percentage inhibition (PI) of the granuloma:

$$
\begin{aligned}
& P G=B-A \\
& P I=\frac{P G}{A} \times 100
\end{aligned}
$$

PG: weight of the granuloma, $A$ = weight of cotton pellet before implantation (100 mg); $B$ = weight of dried cotton pellet after implantation.

\section{Analgesic Effect}

In this study, groups of 5 rats (male and female) and groups of 6 mice (male and female) were used and treated as follows: the control group treated with distilled water at a dose of $0.5 \mathrm{ml} / 100 \mathrm{~g}$; two groups treated with the aqueous extract of Ceiba pentandra at the doses of 400 and $800 \mathrm{mg} / \mathrm{kg}$, one group treated with the standard drug which was either paracetamol (para) $100 \mathrm{mg} / \mathrm{kg}$ for analgesymeter (Cat. No. 37215 Ugo Basile, Italy) induced pain; or Koster (1959) method either, morphine (2 mg/kg) for experiments using heating plates.

\subsection{Analgesymeter Induced Pain Experiment}

The pain is induced by the pressure exerted on the hind paw of animals by the analgesymeter [11]-[14]. One (1) hour after oral administration of the tested products, nociceptive thresholds were determined using the analgesymeter. A constantly increasing pressure was applied on the right hand paw until the rats withdrew the paw. The sensitivity threshold to pain was determined by the following formula: $V=F / T$.

With: $\mathrm{V}=$ Speed of sliding of the needle $(16 \mathrm{~g} / \mathrm{sec}), \mathrm{F}=$ Force causing the withdrawal of the paw by the rat, $\mathrm{T}=$ threshold of pain sensitivity.

\subsection{Acetic Acid-Induced Pain}

The pain was caused in mice by intraperitoneal injection of $0.6 \%$ acetic acid solution [12]. One hour after oral administration of products, $10 \mathrm{ml} / \mathrm{kg}$ of acetic acid was injected intraperitoneally to mice. After injection of acetic acid solution, and a latency period of 5 minutes, the number of writhing made by each mouse was determined within the next 20 minutes [5].

\subsection{Hot Plate Test}

The pain was induced by the hot plate as described by Sabih et al. [3]. One (1) hour after oral administration of test products, animals were placed on the hot plate $\left(56^{\circ} \mathrm{C}\right)$ and the reaction time (licking of the paws, jumping or screaming) was recorded. The maximum time was set at 30 seconds.

\subsection{Statistical Analysis}

The results were expressed as mean \pm ESM. Analysis of variance followed by Student-Fischer $t$ test " $t$ " were performed. The significance level was set at $\mathrm{p}<5 \%$.

\section{Results and Discussion}

Result of anti-inflammatory effects of Ceiba pentandra are shown in Figure 1 and Figure 2. The aqueous extract (400 and $800 \mathrm{mg} / \mathrm{kg}$ ) of Ceiba pentandra inhibits acute inflammation induced by carrageenan (Figure 1). This inhibition is much pronounced two hours after plantar injection of carrageenan with maximum values observed 5 hours after administration (Figure 1). However these effects are less important than those observed with diclofenac, a non steroidal anti-inflammatory used in our study as reference drug. The aqueous extract (400 and 800 $\mathrm{mg} / \mathrm{kg}$ ) inhibited significantly the formation of cotton pellet granuloma (Figure 2) with inhibition percentages of 16.23 and $19.22 \%$ at 400 and $800 \mathrm{mg} / \mathrm{kg}$ respectively. Indeed, carrageenan is a mucosaccharide whose administration in the intraplantar way to rats causes acute inflammation that induce edema, all under the influence of 


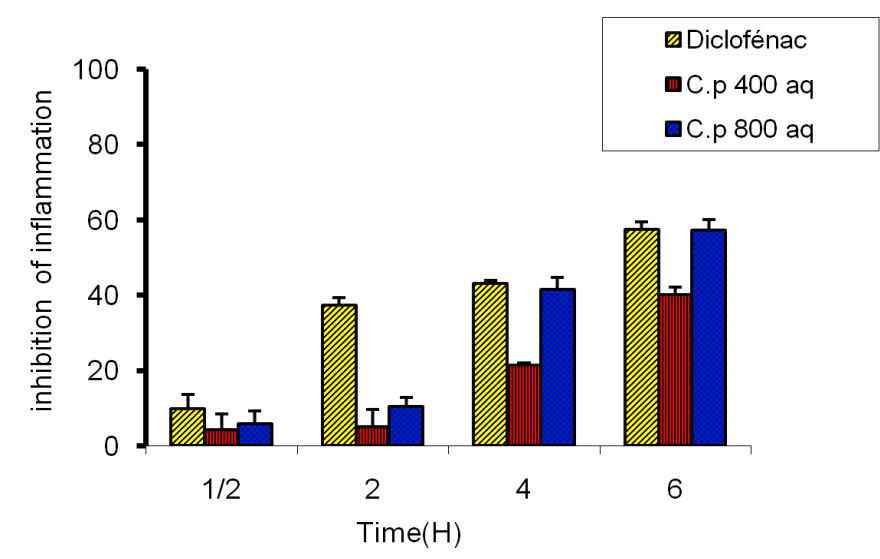

Figure 1. Effect of aqueous extract of Ceiba pentandra on inflammation induced by $1 \%$ carrageenan in rats. Each value represents the mean $\pm \mathrm{ESM}$, versus control group with $\mathrm{N}=5$ rats.

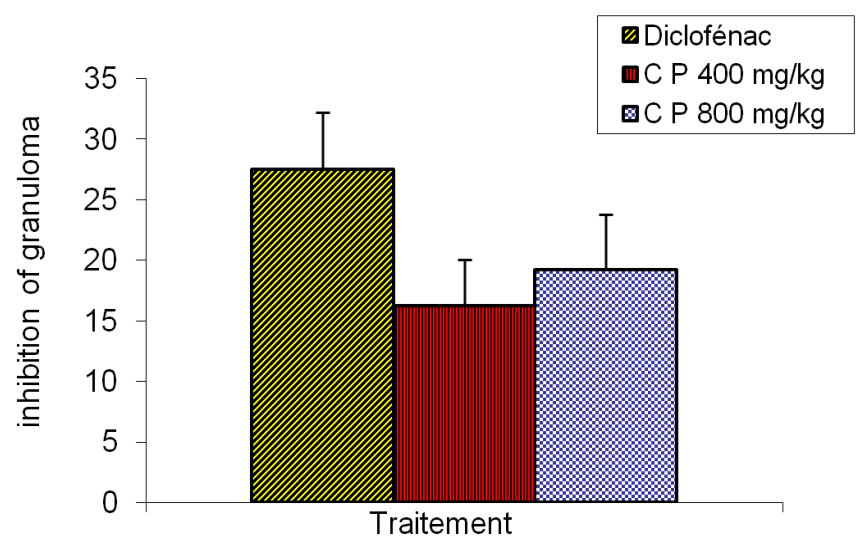

Figure 2. Effect of aqueous extract of Ceiba pentandra on the granulomatous tissu formation in rats. Each value represents the mean $\pm \mathrm{ESM}$; versus control group with $\mathrm{N}=5$ rats.

vasoactive mediators [13]. The aqueous extract of Ceiba pentandra (400 and $800 \mathrm{mg} / \mathrm{kg}$ ) inhibits the progression of edema to varying degrees. This suggests that it interferes with the effects which inhibit the release of mediators involved in these phases of inflammation.

The cotton pellet granuloma is a model of chronic inflammation. The results obtained show that the aqueous extract inhibit the formation of granuloma. This lets suggest that aqueous extract inhibit the synthesis or effects of pro-inflammatory substances. Our results are in agreement with Lin et al., (1992). Indeed, these authors, showed that this plant inhibited the edema induced by the carragenine under plantar in rat.

The results of the analgesic effects of aqueous extracts are presented in Figures 3-5. The aqueous extract (400 and $800 \mathrm{mg} / \mathrm{kg} \mathrm{po}$ ) showed significant analgesic activity. This activity results in an increasing threshold of pain sensitivity (Figure 3), reaction time on the hot plate (Figure 4) and finally reduced number of abdominal writhing induced by $0.6 \%$ acetic acid (Figure 5). Indeed, tissue trauma induced by mechanical stimulation causes local swelling of the traumatized tissue responsible for the release of bradykinin, serotonin, potassium ions and hydrogen [6]. The aqueous extract ( 400 and $800 \mathrm{mg} / \mathrm{kg}$ ) protects against the pain induced by the mechanical stimulation. This suggests that it interferes or inhibits the release of these mediators. These two methods are not really specific. So, we additionally performed the hot plate test using morphine as a reference central analgesic. The fact that the aqueous extract inhibits this type of pain, suggests that it may act as a central analgesic.

The phytochemical analysis of the aqueous extract of Ceiba pentandra previously performed [7] has revealed the presence of flavonoids, tannins, triterpene steroids, and quinones. The anti-inflammatory and analgesic properties of this extract observed in our study can be explained by the presence of flavonoids [9]. 


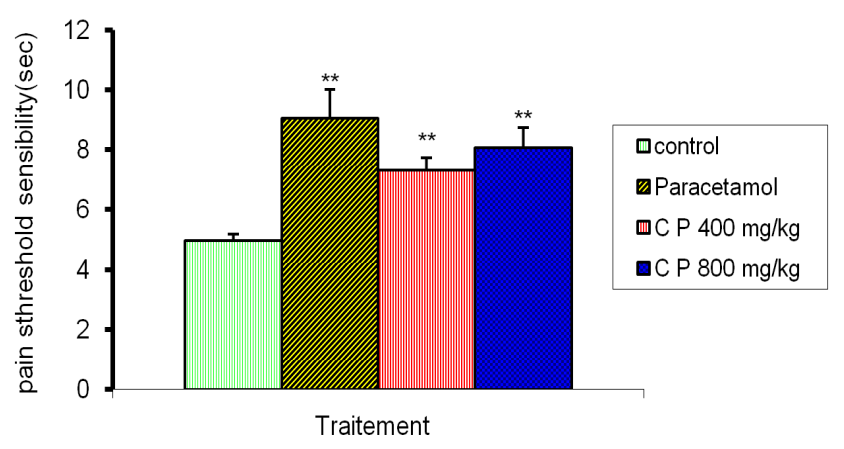

Figure 3. Effect of aqueous extra (aq) of Ceiba pentandra (CP) on the sensitivity threshold of the pain induced by analgesymeter, with ${ }^{* *} \mathrm{p}<0.01$ (Student t-test). Each value represents the mean $\pm \mathrm{ESM}$; versus control group with $\mathrm{N}=5$ rats.

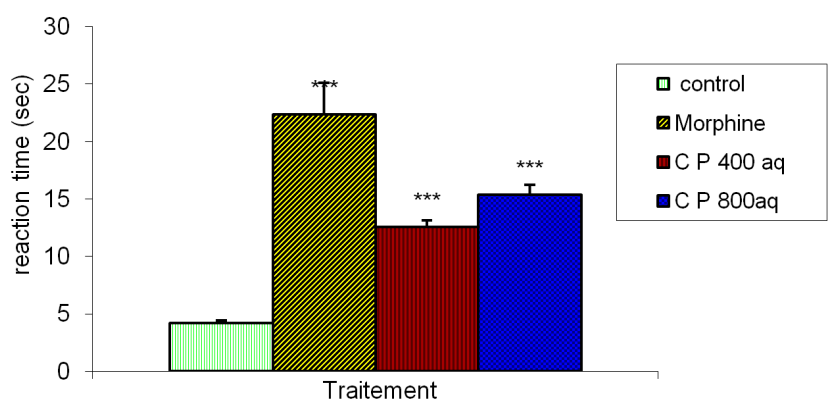

Figure 4. Effect of aqueous extracts (aq) of Ceiba pentandra on the reaction time on the hot plate, with ${ }^{* * *} \mathrm{p}<0.001$ (Student t-test). Each value represents the mean $\pm \mathrm{ESM}$; versus control Grou; with $\mathrm{N}=5$ rats.

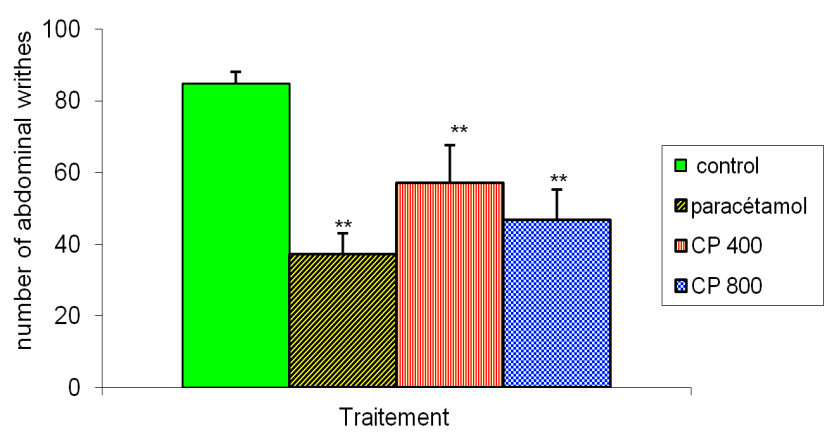

Figure 5. Analgesic effect of aqueous extract of Ceiba pentandra (Cp) against the pain induced by the $0.6 \%$ acetic acid solution in mice, with ${ }^{* * *} \mathrm{p}<0.01$ (Student t-test) Each value represents the mean \pm ESM versus control group.

\section{Conclusion}

This study was initiated to evaluate the anti-inflammatory and analgesic effects of aqueous extract of stem barks of Ceiba pentandra. Indeed, the aqueous extract ( 400 and $800 \mathrm{mg} / \mathrm{kg}$ ) on one hand, inhibits according to the time period, the development of edema induced by carrageenan and the formation of granulation tissue in rats, and on the other hand, the pain caused by analgesimeter and the hot plate in rats. It also protects mice against the abdominal writhes caused by $0.6 \%$ acetic acid. These observed effects could be explained by the presence of flavorous in this extract. These results may explain the traditional use of this plant in the treatment of inflammation and pain. However, its mechanisms of action remain to be clarified. 


\section{Acknowledgements}

Our sincere thanks to: the Traditional Medicine Department (MTD) of the National Institute of Public Health Research (INRSP) in Bamako, Mali, for achieving certain tests; the Agence Universitaire de la Francophonie (AUF) for mobility research grant.

\section{References}

[1] Adjanohoum, E., Ahyi, A.M., Aké Assi, L., et al. (1988) Médecine traditionnelle et pharmacopée. Contribution aux études ethnobotaniques et floristiques en République Populaire du Congo. Edition ACCT, Paris, 605 p.

[2] Longuefosse, J.L. (1995) 100 plantes médicinales de la Caraïbe. Gondwana, 240 p.

[3] Sabih, K., Woods, L.A. and Mitchell, C.L. (1971) Morphine-Induced Hyperalgesia in Rats Tested on the Hot Plate. Journal of Pharmacology and Experimental Therapeutics, 177, 509-513.

[4] Bouquet, A. (1969) Féticheurs et médecine traditionnelle du Congo Brazzaville. ORSTOM 36, 980 p.

[5] Fábio, G.G.M., Jeane, C.V., Ivana, A.N.A., et al. (2001) Antinociceptive and Antiedematogenic Properties and Acute Toxicity of Tabebuia avellanedae Lor. ex Griseb. Inner Bark Aqueous Extract. BMC Pharmacology, 1, 6. http://dx.doi.org/10.1186/1471-2210-1-6

[6] Guirimand, F. (2003) Physiologie de la douleur: Données récentes Version. Néphrologie, 24, 401-407.

[7] Ibara, J.R., Elion Itou, R.D.G., Etou Ossibi, A., et al. (2007) Enquête ethnobotanique à propos de plantes médicinales Congolaise présumées anti-ulcéreuses. Phytothérapia, 5, 118-120. http://dx.doi.org/10.1007/s10298-007-0236-4

[8] Kabangu, K. (1990) Eléments de phytothérapie comparée: Plantes médicinales africaines. Centre de recherches pédagogiques de Kinshasa, 196 p.

[9] Borgi, W., Ghedira, K. and Chouchane, N. (2007) Antiinflammatory and analgesic activities of Zizyphus lotus root barks. Phitoterapia, 78, 16-19.

[10] Mossa, A.C., Rafatulalah, S., Galal, A.M., et al. (1995) Pharmacological Studies of Rhus retinorrha. International Journal of Pharmacognosy, 33, 242-246. http://dx.doi.org/10.3109/13880209509065371

[11] Kissin, I., Cheryl, A., et al. (2000) Acute Tolerance to Continuously Infused Alfentanil: The Role of Cholecystokinin and $N$-Methyl-D-Aspartate-Nitric Oxide Systems. Anesthesia \& Analgesia, 91, 110-116.

[12] Koster, R. and Anderson, M. (1959) Acetic Acid for Analgesic Screening. Federation Proceedings, $18,412$.

[13] Laurent, P.E. and Pérrin, L.F. (1987) Inflammation-Physiopatologie UPSA (Laboratoires), 80 p.

[14] Nsonde Ntandou, G.F., Banzouzi, J.T., Mbatchi, B. et al. (2010) Analgesic and Anti-Inflammatory Effects of Cassia siamea Lam. Stem Bark Extracts. Journal of Ethnopharmacology, 127, 108-111.

http://dx.doi.org/10.1016/j.jep.2009.09.040 
Scientific Research Publishing (SCIRP) is one of the largest Open Access journal publishers. It is currently publishing more than 200 open access, online, peer-reviewed journals covering a wide range of academic disciplines. SCIRP serves the worldwide academic communities and contributes to the progress and application of science with its publication.

Other selected journals from SCIRP are listed as below. Submit your manuscript to us via either submit@scirp.org or Online Submission Portal.
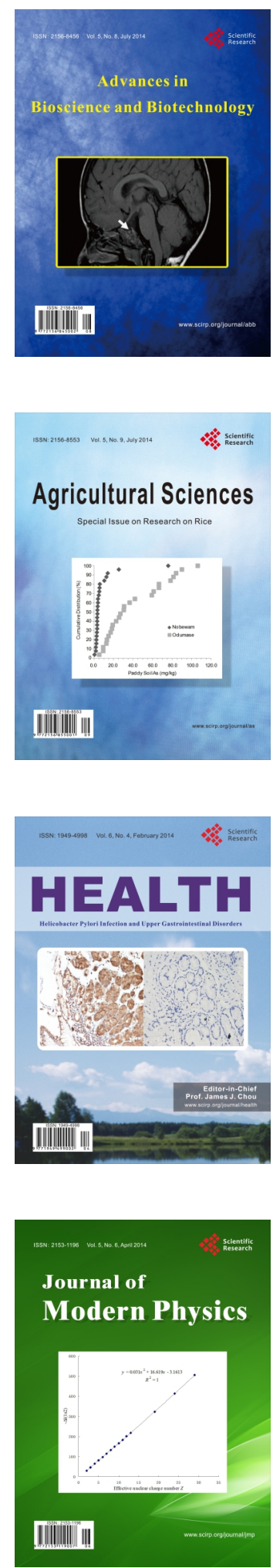
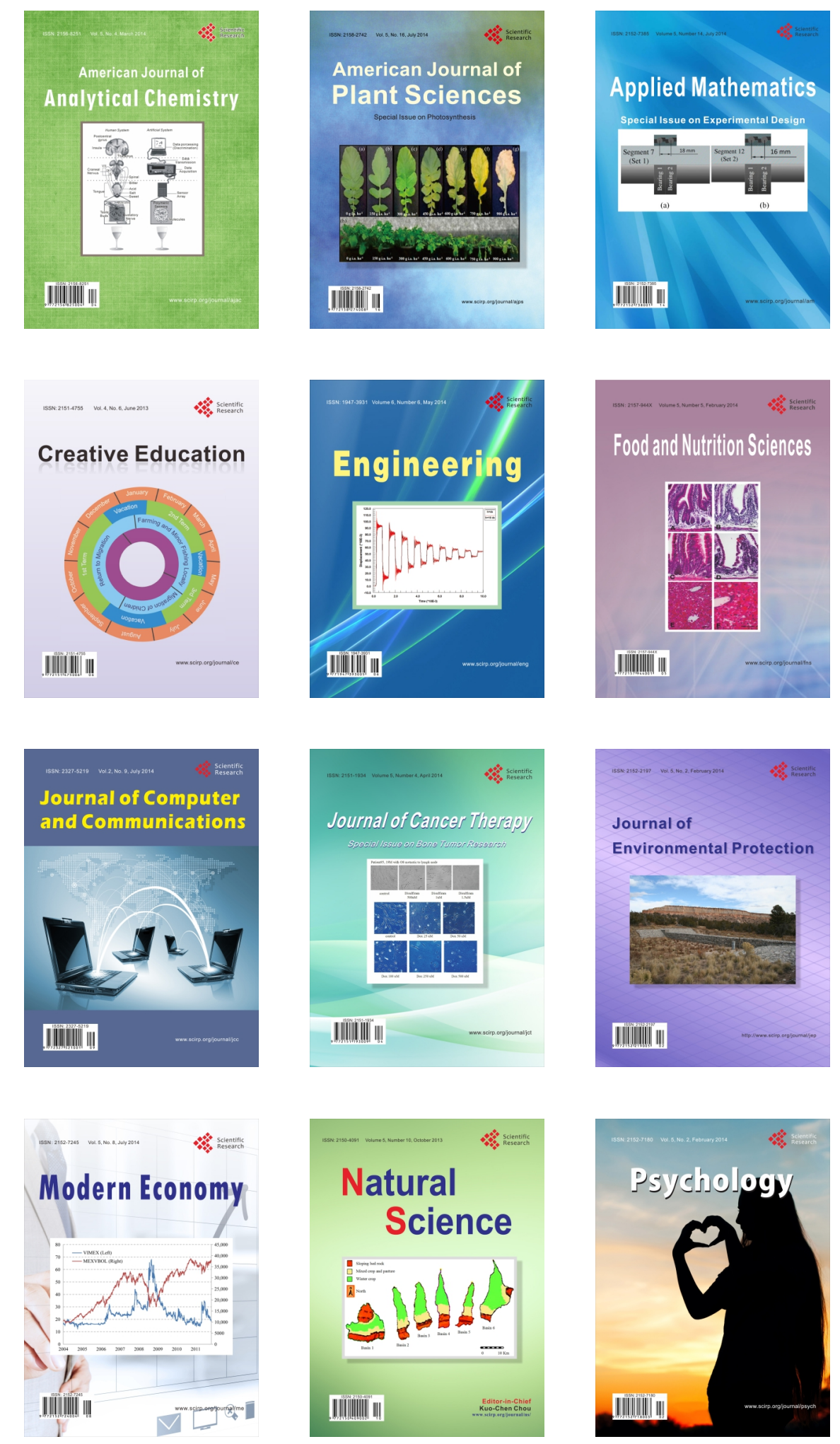